\title{
Teaching a Foreign Language in a Multicultural Context
}

\author{
PhD. Cand. Arti Omeri \\ Department of English Language and Literature, \\ Faculty of Philology and Education, Bedër University, Tirana, Albania \\ email: artomeri@hotmail.com
}

\section{Doi:10.5901/jesr.2014.v4n2p254}

\begin{abstract}
Today, teaching a foreign language in a multicultural classroom is a real challenge for the teachers. They have to cope with many obstacles and difficulties while facing an increasing number of diverse multicultural classes. This study aims to examine the language teaching strategies that a teacher should take into consideration while interacting in a multicultural context. Certainly there is a need to enhance the quality of teaching in such environments. In doing so, a teacher should know and understand very well the cultural diversity and recognize the differences among the various cultural and ethnic groups. Affective intercultural communication helps creating and maintaining an environment that encourages good interpersonal relations in class. The article will also consider the influence of native languages in learning a foreign language. The cultural diversity causes differences in perception and ways of learning a foreign language. Since everyone has the right to get equal education, it is very important that teachers should avoid discrimination on the basis of cultural background, language, and ethnicity. Instead, they should foster tolerance and mutual respect in the class.
\end{abstract}

Keywords: Foreign language, Cultural diversity, Ethnicity, Intercultural, Native language, Multicultural, Interact.

\section{Introduction}

Today, the population of the world is changing rapidly. The movements of the population from one place to another and interracial marriages have contributed in creating a mixed culture society. The large urban areas are becoming more cosmopolitan and smaller ones are also welcoming different ethnicities. This has undoubtedly influenced the education process. In many places, it is very rare to find homogenous classes. Since the major goal of public education is to enable all children to reach their full potential, (Bennett 2001, p.172) it is the duty and the responsibility of the teachers to enhance the quality of teaching. It means that all students should be subject to equal opportunities in education process. Teachers should be well prepared and trained to meet the educational needs of their students.

As Bennett (2001, p.172) underlines that cultural socialization and sense of ethnic identity influence the teaching and learning process, one should accept the differences in races, cultures, religions, and gender in order to overcome communication barriers. In order to improve or draw new programs one should know his audience (Kuri\&Zekaj 2011, p.108).

According to Bennett (2001, p. 173) culture refers to a society's shared beliefs, social values, world-views, and preferred standards of behaving. It is their democratic right to maintain and preserve such values. So it is the duty of teachers to understand and appreciate human diversity while teaching in a multicultural context. During the history there have been many struggles to protect the rights of various ethnic groups regarding education. One of them is the United Negro Improvement Association (UNIA) which still has the largest membership of any African American political organizations (Chapman 2004, p.424). They protested against segregated districts, asked for the same privileges and advantages in education system and for the need of change in curricula (Chapman 2004, p.428).

In her study Capella-Santana (2003, P.188) suggests that multicultural attitudes and knowledge can be changed positively during a teacher preparation program. So if we plan a well -designed multicultural education course in which teachers from different cultural backgrounds share multicultural issues, it would bring positive changes in multicultural attitudes and knowledge of the teachers (Capella-Santana 2003, P.188) .

\section{Strategies Employed by Teachers}

As we know ethnically mixed classes provide a real challenge for the teacher. Gregory \& Jones (2009, p. 776) 
highlighted the main concern resulting from the internationalization of higher education to be the balancing of professional capability with the requirements of a heterogeneous class. To overcome this concern lecturers use several strategies. According to Gregory \& Jones (2009, p. 776) there are four main strategies employed by the teachers:

1) Distancing. It is ideas- focused and structured. In this strategy lecturers tend not to adapt the student needs but instead they keep the focus on ideas in a structured, non-flexible approach.

2) Adapting. It is both ideas-focused and flexible. Lecturers tend to be flexible and change some of their methods and strategies in order to be more inclusive.

3) Clarifying. It is both people -focused and structured. Lecturers tend to make the subject as clear as possible so that students with various needs are fully aware of what is required of them.

4) Relating. It is both people-focused and flexible. Lectures tend to take into consideration the differing needs of individuals and groups and the emphasis is on the development of teacher-student and student-student relationships.

5) Source (Gregory \& Jones (2009, p. 776)

In various situations lecturers can choose the strategy which best can suit the circumstances and context of the class.

\section{Reviewing Multicultural Literature}

When choosing a multicultural text teachers should avoid discrimination on the basis of cultural background, language, and ethnicity. Instead, they should try to be as inclusive as they can. Yoon \& Simpson \& Haag (2010, p.116) have set several important criteria when reviewing multicultural literature. The main three of them are:

1. Ideology through inferred messages

2. Representation of all people

3. Promotion of critical pedagogy

Figure 1: Shows the suggested criteria and guided questions needed to take into consideration when reviewing multicultural literature. (Yoon \& Simpson \& Haag 2010, p.116)

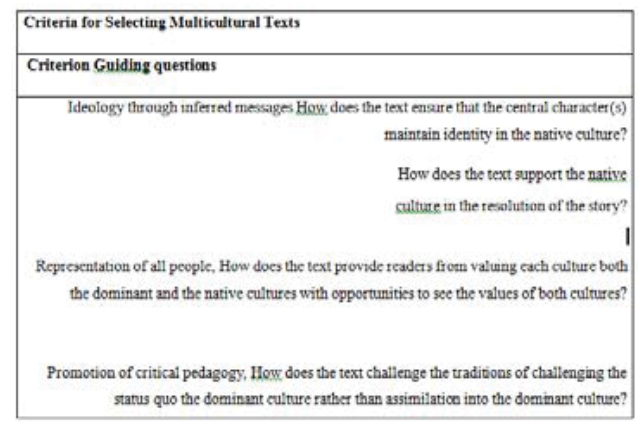

The course selection is very important when teaching in multicultural classes. Teachers should be as much inclusive as they can. Text-books should include a wide variety of text. They should include books that promote cultural pluralism or even go beyond the messages coming from the books.

\section{Native Language}

Native language influences the way how we learn a foreign language. Languages may have similar or different grammatical structure. They might have common or completely different vocabulary. In addition, the nonverbal communication among diverse cultural groups may also be different.

We associate the meaning of a word with our experience and traditions, so the same word might be perceived differently among members of different cultural groups. According to Wade, S.E.\&Fauseke, J.R.\& Thompson,A. (2008, p.405) we construct situated meanings for words from word associations, which become part of our value-laden theories of the world, or cultural models. All conceptions of cultural value systems share the premise that different cultures propose many distinct answers to essentially the same questions posed by the generalities of the human situation 
(Bachmann 2006, p. 724). By using the same language people become members and representative of their communities. Thus language promotes identity and membership of an individual.

There should be a distinction between spoken and written language when considering the influence of native language in learning a foreign language. This is mainly because of their particular characteristics. There are some languages, such as Arabic language which in their written form are completely different from many other languages. So, there should be paid greater attention to such language diversities. As Rodrigues (2002, p. 1017) highlighted, there is a resistance of teachers to learning to teach for diversity. He categorized this resistance into two types: resistance to pedagogical change and resistance to ideological change (Rodrigues 2002, p. 1017).

\section{Conclusion}

As the word is heading evermore towards globalization, there is a greater need for multicultural education in today's society. In order to fulfill the obligation for equity in education, the teachers should be well aware of the needs and cultural background of their students. It is the teacher's duty to enhance the quality of teaching and to serve his/her students unbiased. To achieve that one should understand very well the cultural diversity.

An ideal multicultural classroom appreciates different cultures, ethnicities, languages, religions and values. Teachers should employ various strategies in order to overcome barriers regarding these issues. They should promote intercultural communication among students and between students and teachers. Selection of the text books should be inclusive to all cultures and avoid discrimination of minority groups. Multicultural programs should be designed to help teachers from diverse ethnicities share their beliefs and opinions.

\section{References}

Bennet, C., (2001) Genres of Research in Multicultural Education, Review of Educational Research, Vol. 71, No. 2

Kuri, V. \& Zekaj, Xh. (2011), Sjellja Organizacionale e Liderit "Formimi i Menaxherit dhe Drejtimi i Shkolles", Tirana, Albania

Chapman, Th.K., (2004), Foundations of Multicultural Education: Marcus Garvey and the United Negro Improvement Association, The Journal of Negro Education, Vol. 73, No. 4, Special Focus: Parenting, Family, and Youth

Capella-Santana, N., (2003), Voices of Teacher Candidates: Positive Changes in Multicultural Attitudes and Knowledge, The Journal of Educational Research, Vol. 96, No. 3

Gregory, J. \& Jones, R. (2009) "Maintaining a competence" a grounded theory typlogy of

Approaches to teaching in higher education, Higher Education, Vol. 57, No. 6

Yoon, B. \& Simpsom, A, \& Haag, C. (2010), Asssimilation Ideology: Critically Examining Underlying messages in Multicultural Literature, Journal of Adolescent \& Adult Literacy, Vol. 54, No.2

Wade,S.E.\&Fauseke, J.R.\& Thompson,A. (2008) Prospective Teachers' Problem Solving in Online Peer-Led Dialogues Source: American Educational Research Journal, Vol. 45, No. 2

Bachmann, A. S. (2006), Melting Pot or Tossed Salad? Implications for Designing Effective Multicultural Workgroups, MIR: Management International Review, Vol. 46, No. 6 ,

Rodriguez, J. \& Berryman, C. (2002) Using Sociotransformative Constructivism to Teach for Understanding in Diverse Classrooms: A Beginning Teacher's Journey, American Educational Research Journal, Vol. 39, No. 4 